\title{
Differential Cholinergic Activation of G Proteins in Rat and Mouse Brainstem: Relevance for Sleep and Nociception
}

\author{
GEORGE J. DEMARCO ${ }^{1,2}$ HELEN A. BAGHDOYAN, ${ }^{1}$ AND RALPH LYDIC ${ }^{1 *}$ \\ ${ }^{1}$ Department of Anesthesiology, University of Michigan, Ann Arbor, Michigan 48109 \\ ${ }^{2}$ Unit for Laboratory Animal Medicine, University of Michigan, \\ Ann Arbor, Michigan 48109
}

\begin{abstract}
Murine models are increasingly used for investigations of sleep, yet no previous studies have characterized cholinergic activation of guanine nucleotide binding proteins ( $\mathrm{G}$ proteins) in mouse brainstem nuclei known to regulate sleep. This study used in vitro [ $\left.{ }^{35} \mathrm{~S}\right]$ guanylyl$5^{\prime}-O$ - $\left(\gamma\right.$-thio)-triphosphate $\left(\left[{ }^{35} \mathrm{~S}\right] \mathrm{GTP} \gamma \mathrm{S}\right)$ autoradiography to test the hypothesis that muscarinic cholinergic receptors activate $\mathrm{G}$ proteins in $\mathrm{C57 \textrm {BL } / 6 \mathrm { J }}(\mathrm{B} 6)$ mouse brainstem. The nuclei studied are homologous to those known in rat and cat to modulate sleep and nociception. In B6 mouse, carbachol significantly increased specific binding of $\left[{ }^{35} \mathrm{~S}\right] \mathrm{GTP} \gamma \mathrm{S}$ in the pontine reticular nucleus, caudal part (79\%); pontine reticular nucleus, oral part (131\%); laterodorsal tegmental nucleus (56\%); pedunculopontine tegmental nucleus (86\%); dorsal raphe nucleus (53\%); dorsal medial periaqueductal gray (54\%); and ventrolateral periaqueductal gray (52\%) when compared with basal binding. Carbachol-induced $\mathrm{G}$ protein activation was concentration-dependent and blocked by atropine, demonstrating mediation by muscarinic receptors. $\mathrm{G}$ protein activation by carbachol was heterogeneous across B6 mouse brainstem nuclei. Comparison of $\left[{ }^{35} \mathrm{~S}\right] \mathrm{GTP} \gamma \mathrm{S}$ binding between mouse and rat revealed different magnitudes of $\mathrm{G}$ protein activation in the pontine reticular formation. In the same pontine reticular formation area of $B 6$ mouse where in vitro treatment with carbachol activates $G$ proteins, in vivo microinjection of cholinomimetics causes a rapid eye movement sleep-like state. These data provide the first direct measurement of muscarinic receptor-activated $G$ proteins in B6 mouse brainstem nuclei known in other species to regulate sleep. J. Comp. Neurol. 457:175-184, 2003. @ 2003 Wiley-Liss, Inc.
\end{abstract}

Indexing terms: GTP $\gamma \mathrm{S}$ autoradiography; phenotype; pontine reticular formation; laterodorsal tegmental nucleus; pedunculopontine tegmental nucleus; periaqueductal gray

Most human genes have a mouse homologue (O'Brien et al., 1999). This homology encourages identification of mouse genes influencing disease susceptibility and can point to polymorphisms relevant to human disease (Paigen and Eppig, 2000). Linking successes in mouse genomics to integrative neuroscience will require parallel progress with proteomic and behavioral phenotyping of mouse (Paigen and Eppig, 2000). Phenotyping mouse strains is important for developing a mouse database that can be compared with other species. Much of the current progress in neuroscience has come from studies of rat. The present results provide the first quantitative comparison of guanine nucleotide binding proteins ( $G$ proteins) in brainstem of rat and mouse. In accord with recommendations of The Jackson Laboratory's Mouse Phenome Project, this study used the C57BL/6J (B6) mouse, as a strain from which original phenotyping data are needed (Paigen and Eppig, 2000).

There is good agreement between many laboratories that brainstem cholinergic neurotransmission contributes

Grant sponsor: National Institutes of Health; Grant number: HL65272; Grant number: HL40881; Grant number: HL57120; Grant number: MH45361; Grant sponsor: National Center for Research Resources; Grant number: T32 RR07008.

*Correspondence to: Ralph Lydic, Department of Anesthesiology, University of Michigan, 7433 Medical Sciences Bldg. I, 1150 W. Medical Center Drive, Ann Arbor, MI 48109-0615. E-mail: rlydic@umich.edu

Received 6 June 2002; Revised 27 August 2002; Accepted 31 October 2002. DOI 10.1002/cne.10548

Published online the week of January 20, 2003 in Wiley InterScience (www.interscience.wiley.com). 
to sleep cycle control (Aldrich, 1999; Lydic and Baghdoyan, 1999; Kryger et al., 2000). Directly administering cholinergic agonists or acetylcholinesterase inhibitors into the medial part of cat pontine reticular formation (mPRF) or the homologous pontine reticular nucleus, oral part $(\mathrm{PnO})$ of rat causes a concentration-dependent enhancement of rapid eye movement (REM) sleep (reviewed in Baghdoyan and Lydic, 2002). Acetylcholine (ACh) release in feline $\mathrm{mPRF}$ is significantly greater during REM sleep than during non-REM sleep and wakefulness (Leonard and Lydic, 1997). Cholinergic agonists increase REM sleep by means of muscarinic cholinergic receptors (mAChRs) coupled to pertussis toxin-sensitive $\mathrm{G}$ proteins (Shuman et al., 1995). The mAChRs modulating REM sleep are likely to be postsynaptic and of the M2 subtype (Baghdoyan and Lydic, 1999). Recent studies of intact, unanesthetized mice show for the first time that a REM sleep-like state is caused by microinjection of neostigmine into the $\mathrm{PnO}$ of B6 mouse (Lydic et al., 2002). Neostigmine prevents the enzymatic degradation of ACh. Thus, the ability to cholinergically enhance REM sleep in B6 mouse (Lydic et al., 2002 ) is consistent with in vivo microdialysis data showing that endogenously released ACh can be measured in PnO of B6 mouse (Coleman et al., 2001, 2002).

Cholinergic transmission in brainstem also plays a role in antinociception. Microinjection of cholinomimetics into the mPRF of cat (Kshatri et al., 1998) and PnO of rat (Ishizawa et al., 2000) produces antinociceptive behavior. In rat $\mathrm{PnO}$, the $\mathrm{M} 2$ muscarinic receptor subtype has been suggested to modulate antinociceptive behavior (Ma et al., 2001). The mesencephalic periaqueductal gray (PAG) is a brainstem area known to modulate sleep (Sastre et al., 1996) and nociception (Reynolds, 1969; Besson and Chaouch, 1987). Microinjection of cholinergic agonists into sites throughout the PAG produces antinociceptive behavior (Klamt and Prado, 1991).

The foregoing findings support the view that cell surface mAChRs and their associated G proteins may be regarded as a lower level phenotype that modulates higher level phenotypes such as REM sleep and nociception. No previous studies have characterized cholinergic activation of $G$ proteins in mouse brainstem. Therefore, the present study used in vitro autoradiography to test the hypothesis that carbachol activates $G$ proteins in the brainstem of $B 6$ mouse. Activated $G$ proteins were assayed by using $\left[{ }^{35} \mathrm{~S}\right]$ guanylyl-5'-O- ( $\gamma$-thio)-triphosphate ([ $\left.\left.{ }^{35} \mathrm{~S}\right] \mathrm{GTP} \gamma \mathrm{S}\right)$ binding (Sim et al., 1995, 1997). Seven brainstem nuclei, known in other mammals to regulate sleep and nociception, were selected for quantitative analysis of $\mathrm{G}$ protein activation. Portions of these data have been presented in abstract form (DeMarco et al., 2001).

\section{MATERIALS AND METHODS}

\section{Animals and chemicals}

Male B6 mice (22-24 g) were purchased from The Jackson Laboratory (Bar Harbor, ME). NEN Life Science Products (Boston, MA) was the source for $\left[{ }^{35} \mathrm{~S}\right] \mathrm{GTP} \gamma \mathrm{S}(1,250$ $\mathrm{Ci} / \mathrm{mmol}$ ) and Kodak X-OMAT Blue XB-1 autoradiography film. Sigma Chemical Co. (St. Louis, MO) supplied unlabeled guanosine $5^{\prime}$-( $\gamma$-thio) triphosphate (GTP $\gamma \mathrm{S}$ ), guanosine $5^{\prime}$-diphosphate (GDP), carbachol, and atropine sulfate.

\section{Preparation of tissue sections}

All procedures involving animals were approved by the University of Michigan Committee on Use and Care of Animals and conducted in accordance with the Public Health Service policy on Humane Care and Use of Laboratory Animals (NIH Publication 80-23). Mice were kept on a 12-hour light/dark cycle with lights on at 6:00 AM and were decapitated between 9:30 AM and 11:00 AM. Brains were removed and frozen in a $-30^{\circ} \mathrm{C}$ bilayer of isopentane and bromobutane. Serial, $20-\mu \mathrm{m}$ coronal sections cut on a Hacker Bright OTF cryostat (Fairfield, NJ) were thawmounted onto gelatin-coated glass slides with one pair of adjacent sections per slide. Tissue sections were dried for 2 hours in a cold $\left(5-8^{\circ} \mathrm{C}\right)$ vacuum desiccator, then stored at $-80^{\circ} \mathrm{C}$.

\section{In vitro autoradiography for carbachol- activated $G$ proteins}

The $\left[{ }^{35} \mathrm{~S}\right] \mathrm{GTP} \gamma \mathrm{S}$ binding assay was performed as previously described (Sim et al., 1995, 1997). Brainstem sections from a total of 11 mice were sorted sequentially to ensure that for all mice, each brain region was treated with every binding condition. Tissue sections were soaked in assay buffer (50 mM Tris-HCl, $3 \mathrm{mM} \mathrm{MgCl}_{2}, 100 \mathrm{mM} \mathrm{NaCl}$, and $0.2 \mathrm{mM}$ ethylene glycol tetraacetic acid, $\mathrm{pH} 7.4$ ) for 10 minutes, and preincubated in the same buffer containing 2 $\mathrm{mM}$ GDP for 15 minutes. Brainstem sections then were incubated for 2 hours in a binding bath composed of assay buffer ( $\mathrm{pH} 7.4$ ) containing $0.04 \mathrm{nM}\left[{ }^{35} \mathrm{~S}\right] \mathrm{GTP} \gamma \mathrm{S}$ and $2 \mathrm{mM}$ GDP. Tissue sections from eight mice were treated with either the cholinergic agonist carbachol $(1 \mathrm{mM})$ or carbachol plus the muscarinic antagonist atropine $(0.1 \mathrm{mM})$. Brainstem sections from three mice were incubated with one of four concentrations of carbachol: $1 \times 10^{-7} \mathrm{M}, 1 \times 10^{-5} \mathrm{M}$, $1 \times 10^{-3} \mathrm{M}$, and $1 \times 10^{-2} \mathrm{M}$. Basal G protein activation was assayed by incubating tissue sections without carbachol or atropine. Nonspecific binding (NSB) was determined by incubation with $10 \mu \mathrm{M}$ unlabeled GTP $\gamma \mathrm{S}$ in the absence of carbachol or atropine. After the incubation period, tissue sections were rinsed twice with ice-cold Tris buffer $(\mathrm{pH} 7.0)$ for 2 minutes and once in ice-cold deionized $\mathrm{H}_{2} \mathrm{O}$ for 30 seconds. Tissue sections were dried at room temperature, first with a stream of forced air and then in a vacuum desiccator overnight. Dry tissue sections were placed in stainless steel film cassettes with ${ }^{14} \mathrm{C}$ Microscale standards (Amersham, Arlington Heights, IL; 31-883 nCi/g) and autoradiography film. Seventy-two hours later, films were developed by using a Kodak X-OMAT- 2000A autoprocessor. Hot $\left(80^{\circ} \mathrm{C}\right)$ paraformaldehyde vapor was used to fix the tissue sections (Herkenham and Pert, 1982), which were then stained with cresyl violet.

\section{Data collection and analysis}

A Northern Light illuminator (Imaging Research, Ontario, Canada) was used to backlight cresyl violet-stained tissue sections and the corresponding autoradiograms. Stained sections and autoradiographic films were digitized by using a Cohu (San Diego, CA) CCD camera connected to an Apple G3 computer by means of a digitizing card (Data Translations, Marlboro, MA). The Scion Image (1.62c) program was used to quantify $\mathrm{G}$ protein activation by densitometric analysis of the digitized autoradiograms. Figure 1 shows autoradiograms from rat and mouse brainstem sections treated with carbachol $(1 \mathrm{mM})$. These im- 


\section{Rat}
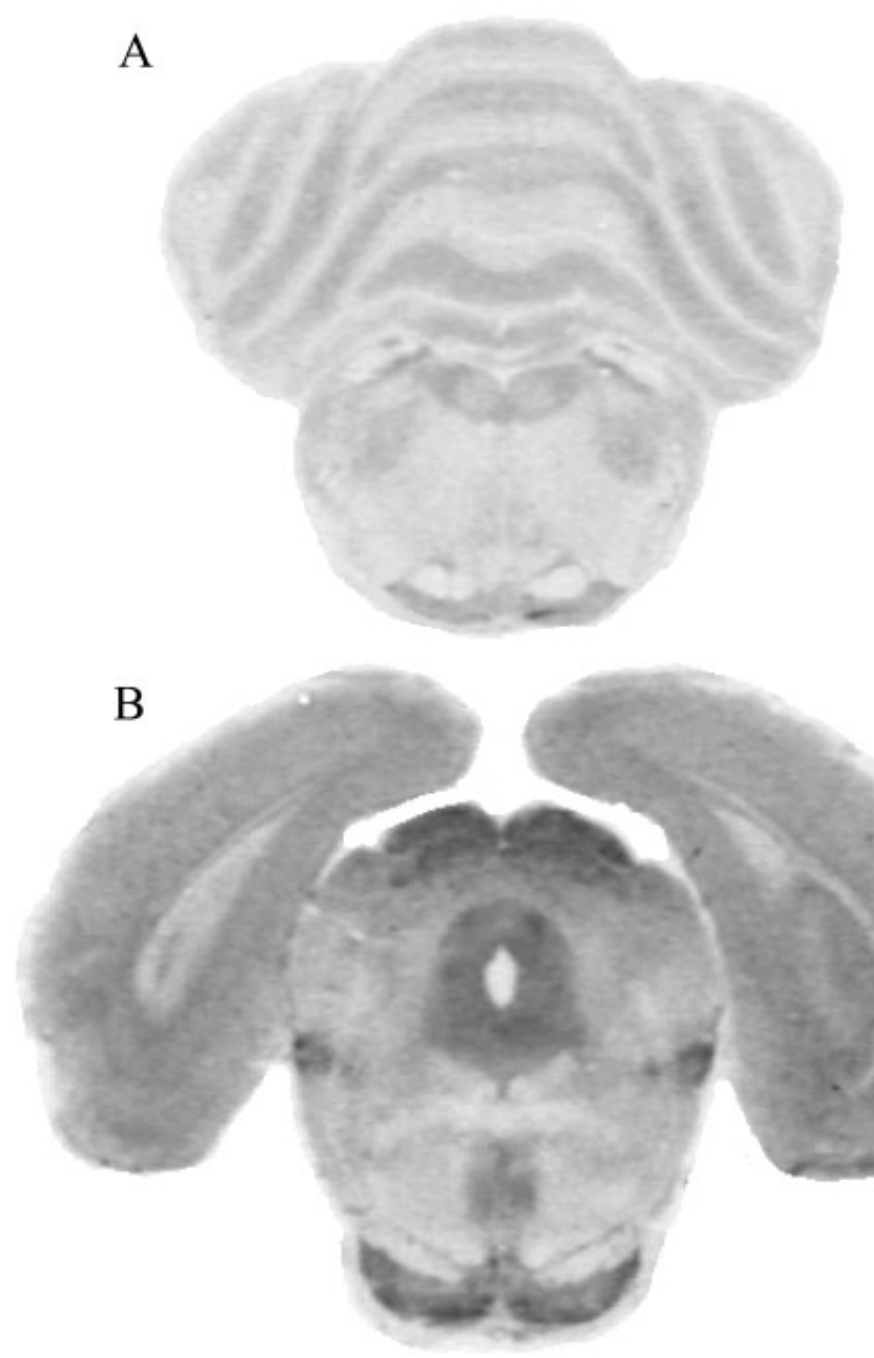

Fig. 1. Autoradiograms showing $\mathrm{G}$ protein activation in brainstem. Coronal sections compare carbachol-stimulated G protein activation in rat (left column) and mouse (right column). A, B: From rat contain nuclei homologous to nuclei present in $\mathbf{C}$ and $\mathbf{D}$ from mouse.
Relative to bregma in the rat atlas (Paxinos and Watson, 1999), A corresponds to -9.30 and B to -7.64 . Relative to bregma in the mouse atlas (Franklin and Paxinos, 1997), C corresponds to -5.40 and D to -4.48 . Scale bar $=1 \mathrm{~mm}$. ages illustrate the ability to resolve specific reticular fields and nuclei. The seven brainstem nuclei studied were dorsomedial periaqueductal gray (DMPAG), dorsal raphe nucleus (DR), pedunculopontine tegmental nucleus (PPT), pontine reticular nucleus (caudal part, $\mathrm{PnC}$ ), pontine reticular nucleus (oral part, $\mathrm{PnO}$ ), laterodorsal tegmental nucleus (LDT), and ventrolateral periaqueductal gray (VLPAG). Mouse brainstem nuclei were localized on the cresyl violet-stained sections according to the mouse brain atlas (Franklin and Paxinos, 1997). Rat PAG nuclei were localized according to the rat brain atlas (Paxinos and Watson, 1999). The anatomic limits of each nucleus were outlined on the digitized, cresyl violet-stained section. The outline then was superimposed onto the corresponding autoradiographic image to ensure accurate localization of each nucleus. Optical density measurements of total binding were obtained from each tissue section.
$\mathrm{C}$

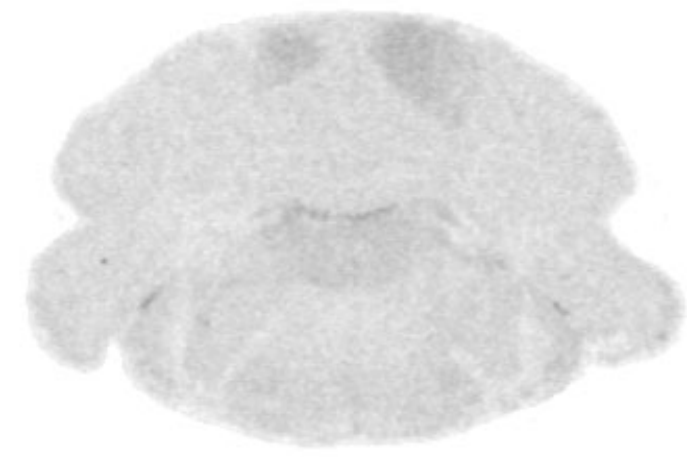

D

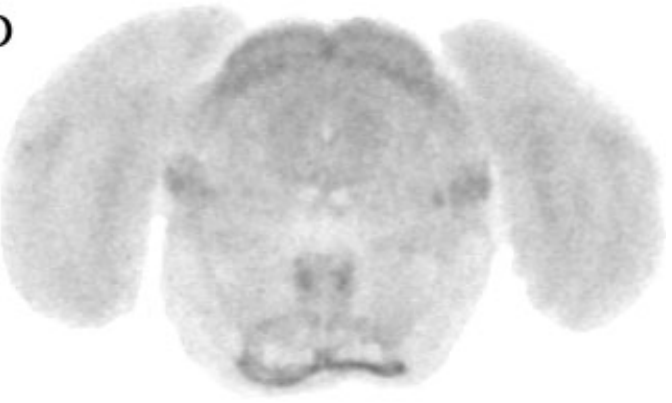

Specific $\left[{ }^{35} \mathrm{~S}\right] \mathrm{GTP} \gamma \mathrm{S}$ binding values were calculated by subtracting mean NSB values for each brainstem nucleus from the total binding values for that nucleus.

Data from mouse were analyzed by a mixed effects model analysis of variance (ANOVA) for repeated measures and post hoc Tukey's multiple comparison test $(P<$ 0.05) using SAS (release 8.8, SAS Institute, Inc., Cary, $\mathrm{NC}$ ). The numerator degrees of freedom (df) equals the number of conditions minus 1 , and the denominator degrees of freedom equals the numerator df multiplied by the number of animals used per nuclei minus 1 . In instances where unequal numbers of animals were used, the SAS program decreases the degrees of freedom accordingly. Data from rat PAG were collected previously (Capece et al., 1998a) and analyzed for the present study by ANOVA. For both rat and mouse, the number of measurements obtained for a given nucleus depended on the 
anterior-to-posterior extent of the nucleus and whether or not the nucleus was bilaterally symmetrical. For example, because mouse PnC spans from bregma -5.02 to -5.68 and is bilaterally symmetrical, the quantitative data included approximately 12 measurements per mouse per treatment condition. For mouse DR, which ranges from bregma -4.04 to -4.36 and is a midline structure, measurements consisted of approximately five values per mouse per treatment condition.

\section{RESULTS}

Figure 2 uses color-coded images of autoradiograms to illustrate total $\left[{ }^{35} \mathrm{~S}\right] \mathrm{GTP} \gamma \mathrm{S}$ binding. Basal levels of $\left[{ }^{35} \mathrm{~S}\right] \mathrm{GTP} \gamma \mathrm{S}$ binding were relatively low and heterogeneous (Fig. 2, top row). Carbachol (1 $\mathrm{mM})$ activated $\mathrm{G}$ proteins throughout the brainstem (Fig. 2, middle row), and atropine blocked carbachol-stimulated $\left[{ }^{35} \mathrm{~S}\right] \mathrm{GTP} \gamma \mathrm{S}$ binding (Fig. 2, bottom row). The images in Figure 2 are from a single mouse and are representative of the group data.

Figure 3A quantifies specific $\left[{ }^{35} \mathrm{~S}\right] \mathrm{GTP} \gamma \mathrm{S}$ binding in seven nuclei of mouse brainstem. For all nuclei studied, carbachol (1 mM) significantly increased $\mathrm{G}$ protein activation above basal levels, and atropine $(0.1 \mathrm{mM})$ reduced carbachol-stimulated $\mathrm{G}$ protein activity to basal levels. The Figure 3A data represent 1,049 measurements from eight mice for VLPAG, DMPAG, DR, PnO, and PnC, 155 measurements from six mice for PPT, and 124 measurements from four mice for LDT. Power analysis indicated that four animals yielded a sufficient sample size for statistical analysis of LDT. ANOVA revealed a significant effect of treatment condition in VLPAG $\left(\mathrm{F}_{(2,14)}=65.02\right.$; $P<0.001)$, DMPAG $\left(\mathrm{F}_{(2,14)}=80.2 ; P<0.001\right), \mathrm{DR}$ $\left(\mathrm{F}_{(2,14)}=137.14 ; P<0.001\right), \operatorname{LDT}\left(\mathrm{F}_{(2,6)}=74.9 ; P<\right.$ $0.001)$, PPT $\left(\mathrm{F}_{(2,10)}=63.5 ; P<0.001\right), \operatorname{PnO}\left(\mathrm{F}_{(2,14)}=\right.$ 121.43; $P<0.001)$, and $\mathrm{PnC}\left(\mathrm{F}_{(2,14)}=71.47 ; P<0.001\right)$.

Although sleep-related brainstem nuclei have been studied in rat with respect to cholinergic activation of $\mathrm{G}$ proteins (Capece et al., 1998a), no previous studies have demonstrated cholinergic activation of $\mathrm{G}$ proteins in rat PAG. Figure 3B illustrates $G$ protein activation quantified for DMPAG and VLPAG of rat. These data represent 264 measurements from six rats. Carbachol (1 mM) significantly increased specific $\left[{ }^{35} \mathrm{~S}\right] \mathrm{GTP} \gamma \mathrm{S}$ binding in DMPAG $\left(\mathrm{F}_{(2,15)}=14.7 ; P<0.001\right)$ and VLPAG $\left(\mathrm{F}_{(2,15)}=19.2 ; P<\right.$ $0.001)$. Atropine $(0.1 \mathrm{mM})$ returned carbachol-stimulated $\left[{ }^{35} \mathrm{~S}\right] \mathrm{GTP} \gamma \mathrm{S}$ binding to basal levels.

This study next sought to determine whether carbachol-induced $\mathrm{G}$ protein activation was concentrationdependent and could be saturated. The autoradiograms in Figure 4A demonstrate the concentration response for carbachol-stimulated $\left.{ }^{35} \mathrm{~S}\right] \mathrm{GTP} \gamma \mathrm{S}$ binding in mouse brainstem. Increase in $\left[{ }^{35} \mathrm{~S}\right] \mathrm{GTP} \gamma \mathrm{S}$ binding corresponding to $\mathrm{G}$ protein activation are apparent at carbachol concentrations greater than $1 \times 10^{-7} \mathrm{M}$. These images are representative of those used to obtain quantitative concentration-response data. Figure 4B shows representative autoradiograms of the concentration response for carbachol-stimulated $\left[{ }^{35} \mathrm{~S}\right] \mathrm{GTP} \gamma \mathrm{S}$ binding in rat brainstem. Similar to autoradiograms from mouse, the Figure 4B rat autoradiograms show increases in $\left[{ }^{35} \mathrm{~S}\right] \mathrm{GTP} \gamma \mathrm{S}$ binding at carbachol concentrations greater than $1 \times 10^{-7} \mathrm{M}$.

Figure 5A shows that, in mouse brainstem, carbachol-induced $\left[{ }^{35} \mathrm{~S}\right] \mathrm{GTP} \gamma \mathrm{S}$ binding was concentration- dependent and could be saturated. Due to the small size of the mouse brainstem and the need to test each concentration of carbachol in tissue sections from the same mouse, two brainstem regions with relatively long rostral-tocaudal extents were selected for concentration-response analysis. These were the pontine reticular formation (PRF) and the PAG. The PRF was defined to include PnO and PnC, and the PAG was defined to include VLPAG and DMPAG. The Figure 3A data showed that there was no significant difference in $\left[{ }^{35} \mathrm{~S}\right] \mathrm{GTP} \gamma \mathrm{S}$ binding between $\mathrm{PnO}$ and $\mathrm{PnC}$ for any treatment condition, providing a rationale for combining measures from these nuclei. Similarly, there was no difference in $\mathrm{G}$ protein activation between VLPAG and DMPAG (Fig. 3A), and measures from these two areas were combined for the concentration-response analysis. The Figure 5A data summarize 376 measurements obtained from three mice. ANOVA revealed a significant effect of carbachol concentration in $\mathrm{PRF}\left(\mathrm{F}_{(4,8)}=\right.$ 16.43; $P<0.0006)$ and PAG $\left(\mathrm{F}_{(4,8)}=29.06 ; P<0.0001\right)$. Post hoc Tukey's analysis demonstrated that $G$ protein activation in the PRF was significantly increased over basal values by $10^{-3} \mathrm{M}(1 \mathrm{mM})$ and $10^{-2} \mathrm{M}(10 \mathrm{mM})$ carbachol. In mouse PAG, $\mathrm{G}$ protein activation was significantly increased over basal values by $10^{-5} \mathrm{M}(0.01 \mathrm{mM})$, $10^{-3} \mathrm{M}(1 \mathrm{mM})$, and $10^{-2} \mathrm{M}(10 \mathrm{mM})$ carbachol.

Figure $5 \mathrm{~B}$ demonstrates that, in rat PAG, carbachol-induced $\left[{ }^{35} \mathrm{~S}\right] \mathrm{GTP} \gamma \mathrm{S}$ binding was concentrationdependent and could be saturated. As with mouse, there was no significant difference in $\left.{ }^{35} \mathrm{~S}\right] \mathrm{GTP} \gamma \mathrm{S}$ binding between VLPAG and DMPAG (Fig. 3B). Therefore, Figure $5 \mathrm{~B}$ combines measures from VLPAG and DMPAG as a function of carbachol concentration. The Figure $5 \mathrm{~B}$ data were obtained from 339 measurements in three rat brains. ANOVA revealed a significant effect of carbachol concentration on $\left[{ }^{35} \mathrm{~S}\right] \mathrm{GTP} \gamma \mathrm{S}$ binding in PAG. G protein activation by $1 \mathrm{mM}$ carbachol was significantly greater than basal values.

Figure 6 compares carbachol-stimulated G protein activation as a percentage of basal $\left[{ }^{35} \mathrm{~S}\right] \mathrm{GTP} \gamma \mathrm{S}$ binding between mouse and rat for five brainstem regions. ANOVA indicated a statistically significant region main effect for carbachol-stimulated $\left.{ }^{35} \mathrm{~S}\right] \mathrm{GTP} \gamma \mathrm{S}$ binding in mouse $\left(\mathrm{F}_{(6,36)}=63.86 ; P<0.0001\right)$ and $\operatorname{rat}\left(\mathrm{F}_{(6,30)}=142.9 ; P<\right.$ $0.0001)$. The greatest increase over basal $\left[{ }^{35} \mathrm{~S}\right] \mathrm{GTP} \gamma \mathrm{S}$ binding was in PRF (105\%) for mouse and LDT (75\%) for rat. The lowest percentage increase over basal binding was found in DR and PAG (53\%) for mouse and PAG (43\%) for rat. Student's $t$-test revealed statistically significant differences in $\mathrm{G}$ protein activation between mouse PRF and rat $\mathrm{PRF}$.

\section{DISCUSSION}

The present data demonstrate, for the first time, cholinergically mediated $G$ protein activation in brainstem nuclei of $\mathrm{B} 6$ mouse. Stimulation of $\mathrm{G}$ proteins by carbachol was heterogeneous across nuclei, concentrationdependent, and blocked by atropine. This study also provides the first comparison of cholinergically induced $G$ protein activation between specific brainstem nuclei of mouse and rat. Data were obtained by using in vitro $\left[{ }^{35} \mathrm{~S}\right] \mathrm{GTP} \gamma \mathrm{S}$ autoradiography to visualize and quantify $\mathrm{G}$ protein activation. This assay is unique in permitting precise anatomic localization of activated $G$ proteins (Figs. $1,2,4)$ and quantification of specific $\left[{ }^{35} \mathrm{~S}\right] \mathrm{GTP} \gamma \mathrm{S}$ binding 

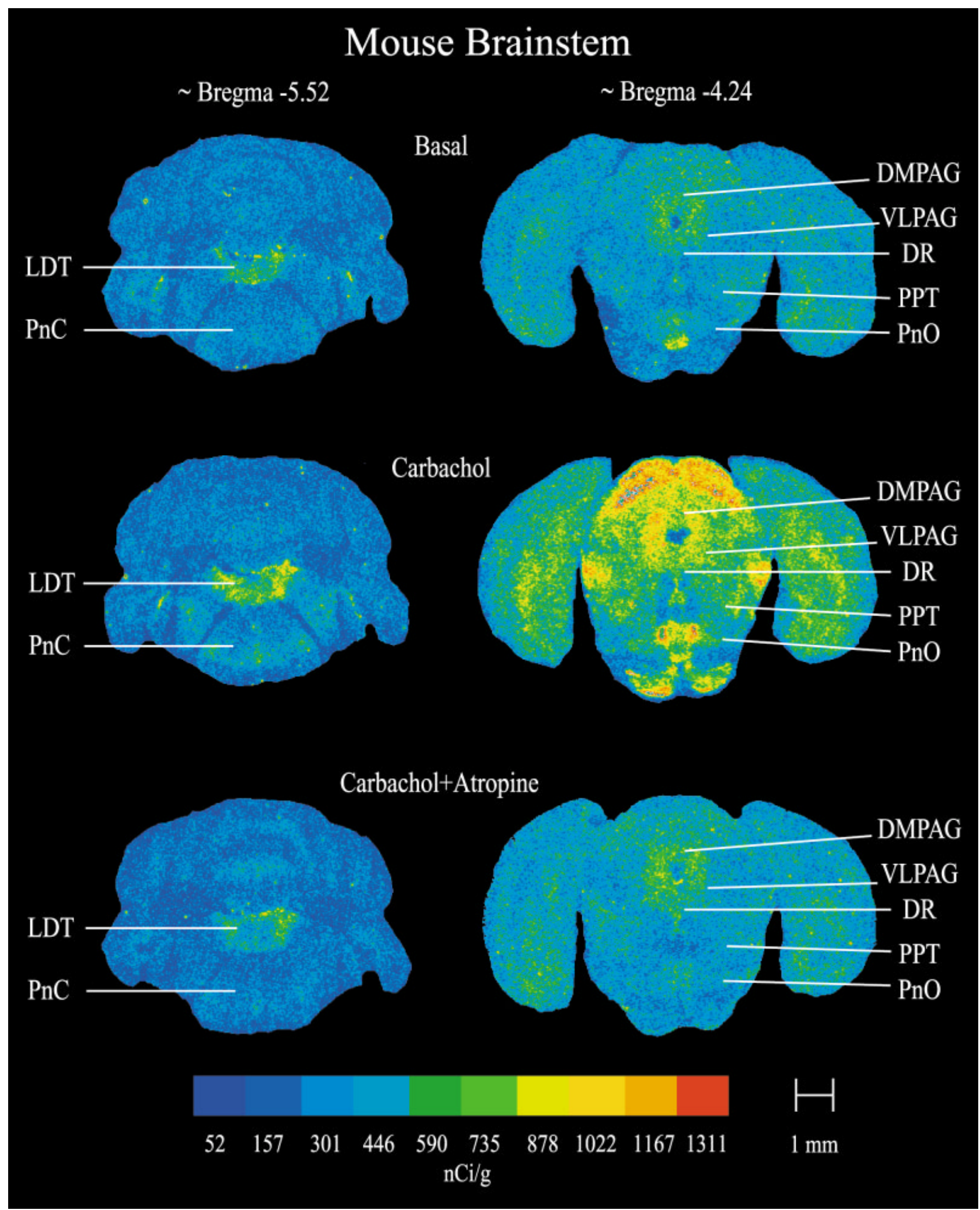

Fig. 2. G protein activation in mouse brainstem. Color-coded autoradiograms of coronal sections show total $\left[{ }^{35} \mathrm{~S}\right]$ guanylyl-5' $-\mathrm{O}-(\gamma-$ thio)-triphosphate $\left(\left[{ }^{35} \mathrm{~S}\right] \mathrm{GTP} \gamma \mathrm{S}\right)$ binding for three treatment conditions (rows) at two brainstem levels (columns). Locations of the seven nuclei studied are indicated for each section. Note that the sections treated simultaneously with carbachol $(1 \mathrm{mM})$ and atropine $(0.1 \mathrm{mM})$ showed levels of $\mathrm{G}$ protein activation similar to basal, indicating that the carbachol-stimulated increases in $\left.{ }^{35} \mathrm{~S}\right] \mathrm{GTP} \gamma \mathrm{S}$ binding resulted from activation of muscarinic receptors. Scale bar $=1 \mathrm{~mm}$. 


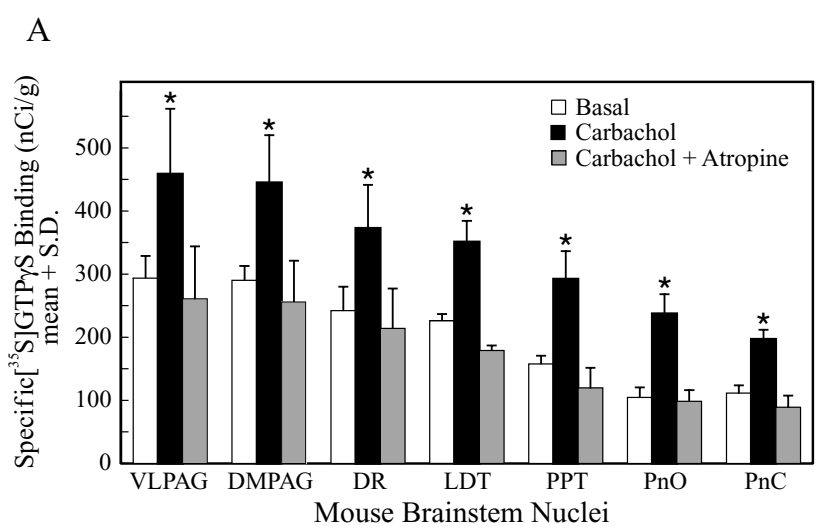

$\mathrm{B}$

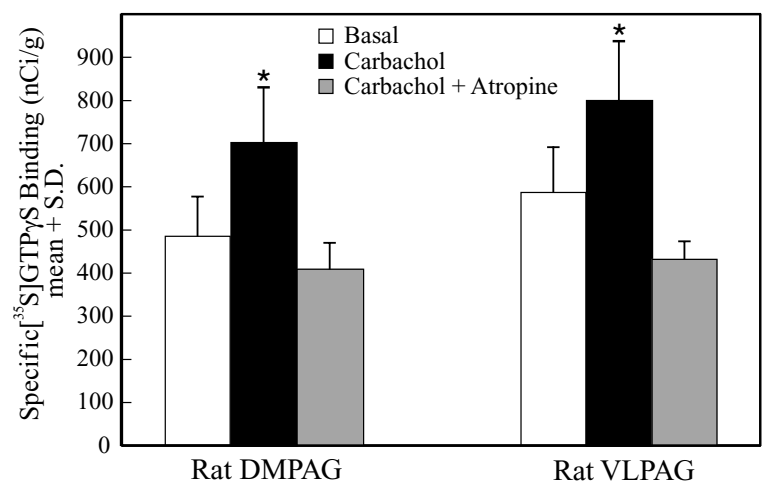

Fig. 3. Carbachol-stimulated $\left[{ }^{35} \mathrm{~S}\right]$ guanylyl-5'-O-( $\gamma$-thio)triphosphate $\left.\left({ }^{35} \mathrm{~S}\right] \mathrm{GTP} \gamma \mathrm{S}\right)$ binding in mouse and rat brainstem. A: Quantitative analysis revealed that, in mouse, carbachol caused G protein activation, and atropine blocked the carbachol-induced activation in each of the seven nuclei studied. These data demonstrate that $\mathrm{G}$ protein activation was mediated by muscarinic receptors. Asterisks indicate significant increases in $G$ protein activation over respective basal and carbachol + atropine levels $(P<0.0001)$. B: Carbachol activated $\mathrm{G}$ proteins in rat dorsomedial (DMPAG) and ventrolateral (VLPAG) periaqueductal gray. Carbachol activation of G proteins was blocked by atropine, indicating mediation by muscarinic cholinergic receptors. Asterisks indicate significant increases in G protein activation over respective basal and carbachol + atropine levels $(P<0.01)$

(Figs. 3, 5, 6) in the same tissue samples (Sóvágó et al., 2001).

\section{Carbachol-stimulated $\left[{ }^{35} \mathrm{~S}\right] \mathrm{GTP} \gamma \mathrm{S}$ binding in mouse and rat brainstem was mediated by muscarinic cholinergic receptors}

Two criteria must be met to demonstrate that a process is receptor mediated. One is the blocking of ligand action by a receptor antagonist. The second criterion is a concentration-response that saturates. The present data satisfy both criteria.

Atropine is a competitive inhibitor of $\mathrm{mAChRs}$, and atropine blocked carbachol-stimulated $\mathrm{G}$ protein activation in mouse (Figs. 2, 3A) and rat (Fig. 3B). This finding supports the conclusion that carbachol-induced $\mathrm{G}$ protein activation in mouse brainstem and rat PAG is mediated by $\mathrm{mAChRs}$. The present $\mathrm{G}$ protein data are congruent with data showing that atropine blocks carbachol-stimulated $\left.{ }^{35} \mathrm{~S}\right] \mathrm{GTP} \gamma \mathrm{S}$ binding in cortical membranes from human brain (Gonzalez-Maeso et al., 2000) and in REM sleeprelated brainstem nuclei of rat (Capece et al., 1998b). The present results are consistent with in vivo data demonstrating that muscarinic antagonists inhibit cholinergically induced REM sleep in cat (Baghdoyan et al., 1984; Velazquez-Moctezuma et al., 1990; Baghdoyan and Lydic, 1999) and rat (Imeri et al., 1994; Bourgin et al., 1995).

$\mathrm{G}$ protein activation was concentration-dependent in mouse pontine reticular formation and mouse and rat periaqueductal gray (Fig. 5). The concentration-response curves for PRF and PAG also exhibited saturation, consistent with a receptor mediated process. These findings parallel previously reported concentration-response curves for carbachol-stimulated $\left.{ }^{35} \mathrm{~S}\right] \mathrm{GTP} \gamma \mathrm{S}$ binding in chick optic tectum (Kurkinen et al., 1997) and rat PRF (Capece et al., 1998a). Studies microinjecting cholinomimetics into the PRF in vivo have demonstrated the concentration-dependent nature of cholinergically enhanced REM sleep in cat (Baghdoyan et al., 1984, 1989) and rat (Bourgin et al., 1995).

\section{Comparison of carbachol-stimulated $G$ protein activation in rat and mouse brainstem}

Activation of $\mathrm{G}$ proteins by carbachol was not significantly different between the $\mathrm{PnC}$ and $\mathrm{PnO}$ regions of mouse pontine reticular formation (Fig. 3A). In mouse (Fig. 3A) and rat (Fig. 3B), G protein activation was not different between the DMPAG and VLPAG regions of the periaqueductal gray. In both mouse and rat, activation of $\mathrm{G}$ proteins by carbachol was heterogeneous across the other nuclei studied. In mouse, the largest percentage change from basal activation was noted in the PRF, whereas in rat, the largest change was noted in the LDT (Fig. 6). The lowest percentage change from basal activation for both species was seen in DR and PAG. These findings are consistent with other comparative studies of mouse and rat. For example, the distribution of galaninergic immunoreactivity in mouse brain is similar to that of rat in most areas but is significantly different in the olfactory bulb, thalamus, pretectum, and medulla (Perez et al., 2001). Cholinergic innervation as measured by choline acetyltransferase activity is similar in mouse and rat corpus striatum, thalamus, basal forebrain, and pons, but significantly different in the neocortex (Owasoyo and Olowookorun, 1982; Gordon and Finch, 1984; Kitt et al., 1994). Statistically significant differences were noted between carbachol-stimulated $\left[{ }^{35} \mathrm{~S}\right] \mathrm{GTP} \gamma \mathrm{S}$ binding in mouse and rat $\mathrm{PRF}$ (Fig. 6).

\section{Functional implications}

Carbachol was chosen as the agonist to activate receptor-coupled G proteins because of the good consensus that brainstem ACh significantly modulates electroencephalographic and behavioral arousal (Lydic and Baghdoyan, 1998, 1999; Aldrich, 1999; Kryger et al., 2000). The present functional neuroanatomic data can be related to in vivo pharmacologic data regarding the cholinergic modulation of REM sleep. Microinjection of cholinomimetics into feline PRF regions homologous to mouse PRF causes REM sleep to increase by several hundred percent (Baghdoyan and Lydic, 1999). Similar microinjections into homologous PRF regions of rat either failed to consistently 
A. Mouse

\section{Basal}

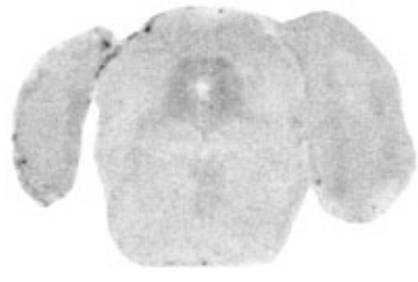

$1 \times 10^{-7} \mathrm{M}$

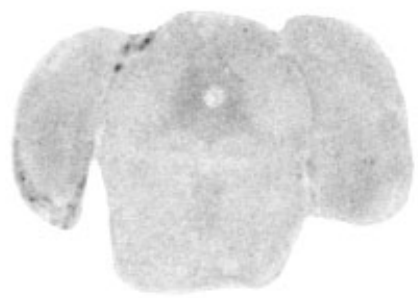

$1 \times 10^{-5} \mathrm{M}$

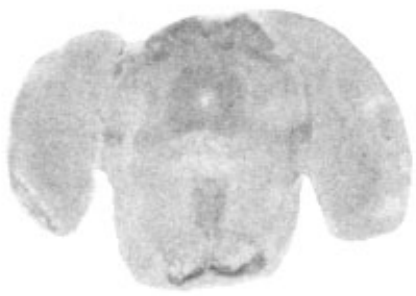

$1 \times 10^{-3} \mathrm{M}$

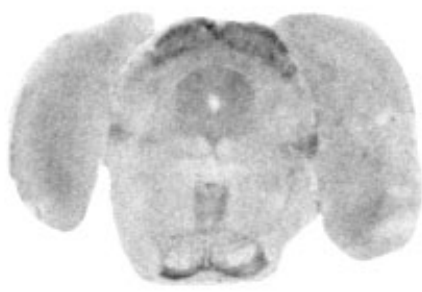

$1 \times 10^{-2} \mathrm{M}$

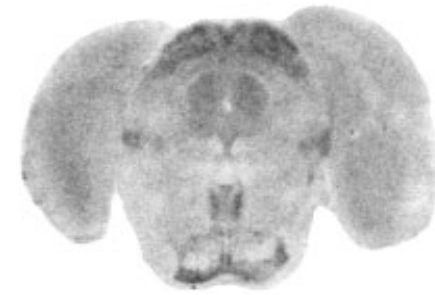

B. Rat
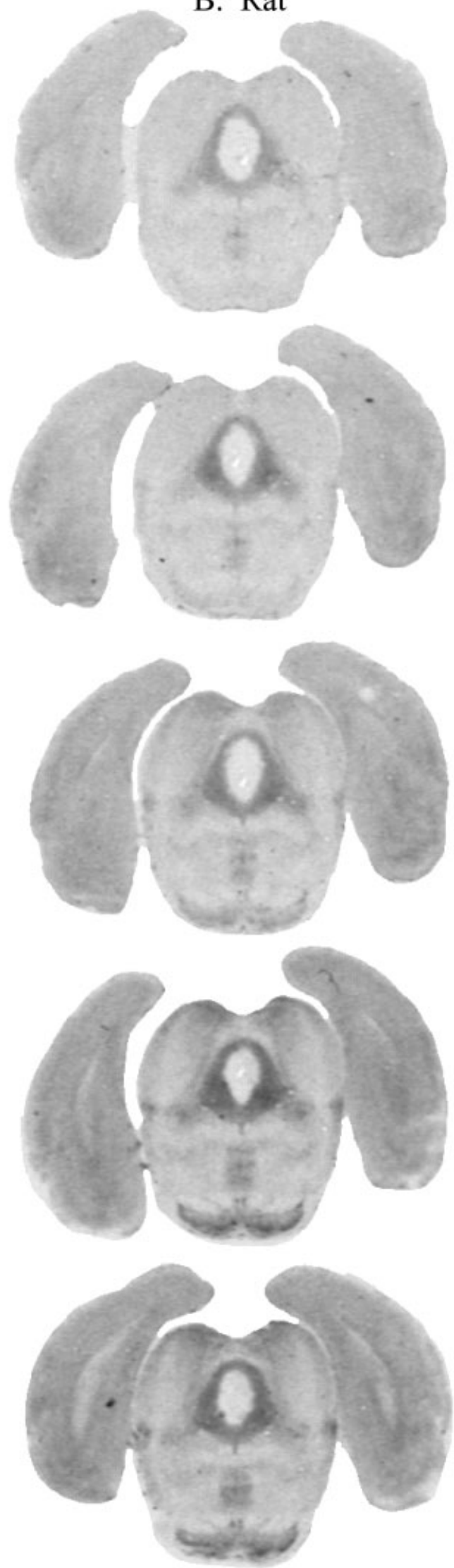

mouse brain extend from bregma -4.60 (top) to -4.24 (bottom) (Franklin and Paxinos, 1997). B: Sequential coronal sections from the same rat brainstem span from bregma -8.00 (top) to -7.64 (bottom; Paxinos and Watson, 1999). Scale bar $=1 \mathrm{~mm}$. carbachol. Autoradiograms show sequential sections from cauc (basal) to rostral. Carbachol concentration ranged from $1 \times 10^{-7} \mathrm{M}$ (top) to $1 \times 10^{-2} \mathrm{M}$ (bottom). A: These coronal sections from the same 


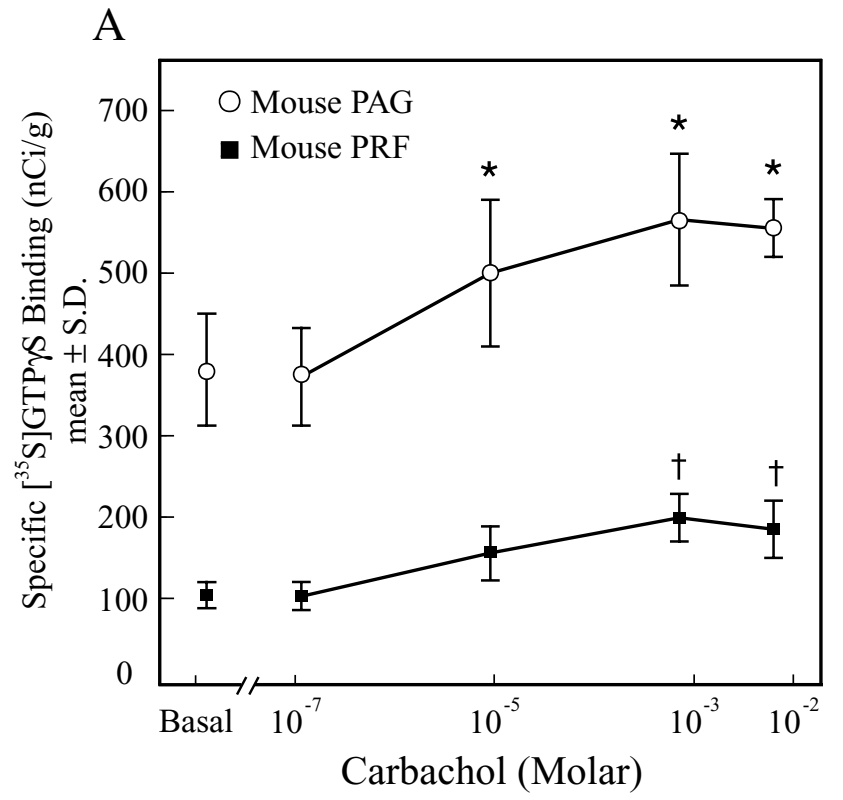

B

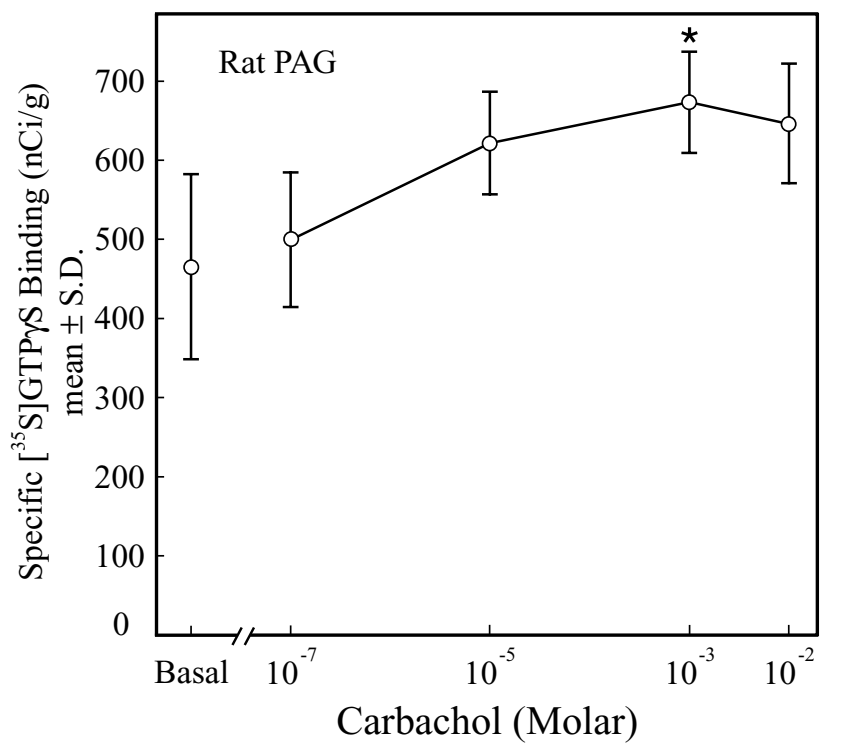

Fig. 5. Concentration-response curves for specific $\left[{ }^{35} \mathrm{~S}\right]$ guanylyl$5^{\prime}-O$ - $\left(\gamma\right.$-thio)-triphosphate $\left(\left[{ }^{35} \mathrm{~S}\right] \mathrm{GTP} \gamma \mathrm{S}\right)$ binding. A: Carbachol caused a concentration-dependent increase in $G$ protein activation in the pontine reticular formation (PRF) and periaqueductal gray (PAG) of mouse. Asterisks and crosses indicate significant increases in G protein activation over respective basal values $(P<0.01)$. B: In the periaqueductal gray (PAG) of rat, carbachol caused a concentrationdependent increase in $G$ protein activation. The asterisk indicates a significant increase in $\mathrm{G}$ protein activation over basal $(P<0.05)$. Mouse and rat data are consistent with the conclusion that carbacholstimulated $\mathrm{G}$ protein activation is receptor mediated.

increase REM sleep (Deurveilher et al., 1997) or increased REM sleep by approximately 50\% (Bourgin et al., 1995). Thus, there are important species differences between cat and rat with respect to cholinergic triggering of REM sleep.

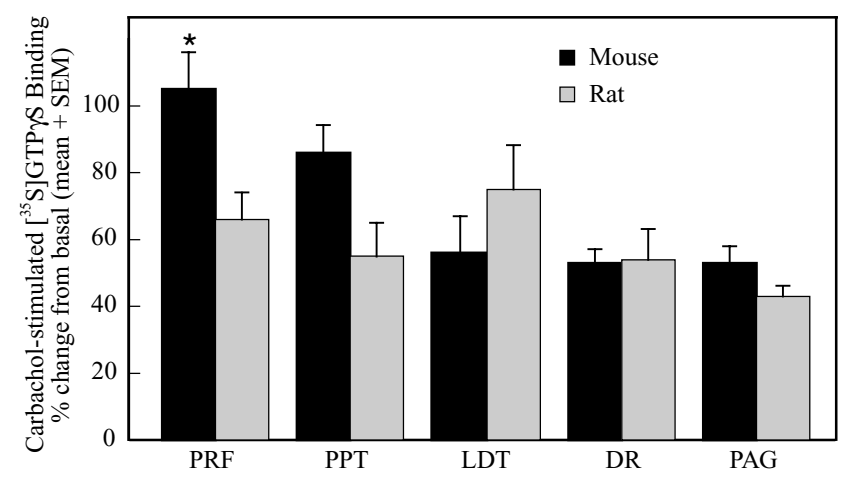

Fig. 6. Comparison of carbachol-stimulated $\left[{ }^{35}\right.$ S]guanylyl-5' $-O-(\gamma-$ thio)-triphosphate $\left(\left[{ }^{35} \mathrm{~S}\right] \mathrm{GTP} \gamma \mathrm{S}\right)$ binding in mouse and rat brainstem. G protein activation by $1 \mathrm{mM}$ carbachol was heterogeneous across nuclei in both mouse and rat. G protein activation was significantly greater in mouse pontine reticular formation (PRF) than in rat PRF $\left({ }^{*} P<0.05\right)$. Rat data for PRF, pedunculopontine tegmental nucleus (PPT), laterodorsal tegmental nucleus (LDT), and dorsal raphe nucleus (DR) are from (Capece et al., 1998a).

Microinjection data from rat also indicate that cholinergic stimulation of $\mathrm{PnC}$ is significantly less efficacious in causing REM sleep enhancement than cholinergic stimulation of $\mathrm{PnO}$ (Bourgin et al., 1995). These functional data can be contrasted with the observations of no significant difference in cholinergic activation of $\mathrm{G}$ proteins between $\mathrm{PnO}$ and $\mathrm{PnC}$ of mouse (Fig. 3A) or rat (Capece et al., 1998a). Similarly, there is a homogeneous distribution of mAChRs across $\mathrm{PnO}$ and $\mathrm{PnC}$ of rat (Baghdoyan, 1997). Thus, the REM sleep-enhancing actions of carbachol are significantly greater in rat $\mathrm{PnO}$ than $\mathrm{PnC}$ (Bourgin et al., 1995) in the absence of significant differences between $\mathrm{PnO}$ and $\mathrm{PnC}$ in density of mAChRs (Baghdoyan, 1997) or cholinergically activated G proteins (Capece et al., 1998a). Figure 6 shows that the same concentration of carbachol caused significantly greater $G$ protein activation in mouse $\mathrm{PRF}$ than in rat PRF. One function of $\mathrm{G}$ proteins is amplification of transmembrane signaling, and the Figure 6 data suggest that REM sleep in mouse also will be increased by pontine administration of cholinomimetics. This implication is supported by three new findings. First, $\mathrm{PnO}$ microinjection of the acetylcholinesterase inhibitor neostigmine causes REM sleep enhancement in B6 mouse (Lydic et al., 2002). Second, the cholinergic agonist carbachol also increases REM sleep when microinjected into PnO of B6 mouse (Fig. 7). Third, microdialysis data show that endogenous $\mathrm{ACh}$ is released in $\mathrm{PnO}$ of $\mathrm{B} 6$ mouse (Coleman et al., 2001, 2002).

In rat periaqueductal gray, microinjection of carbachol causes antinociception (Guimaraes et al., 2000). The present data show that, in mouse and rat periaqueductal gray, $\mathrm{G}$ proteins were activated by carbachol (Figs. 2, 3, 5). Considered together, these data suggest that microinjection of cholinergic agonists into periaqueductal gray of B6 mouse will cause antinociception. This speculation is open to future investigation.

\section{Limitations and conclusions}

The $\left[{ }^{35} \mathrm{~S}\right] \mathrm{GTP} \gamma \mathrm{S}$ assay provides novel information regarding the distribution of signal transduction pathways activated by specific ligands. Although limitations of the 


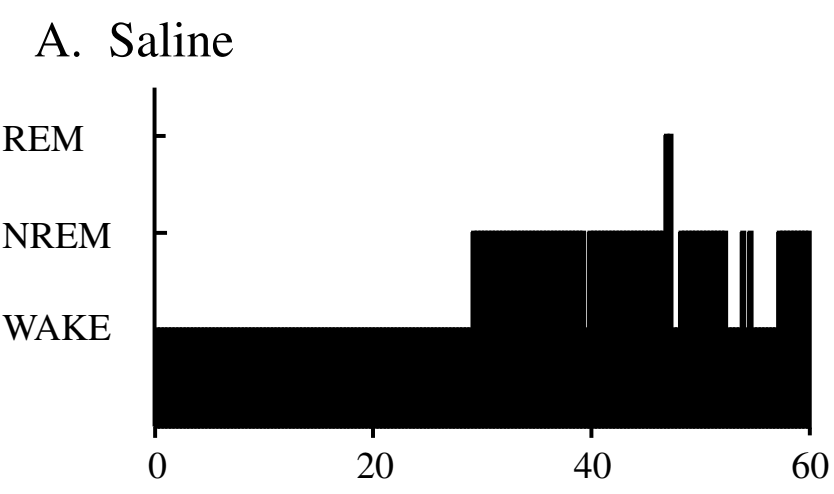

B. Carbachol

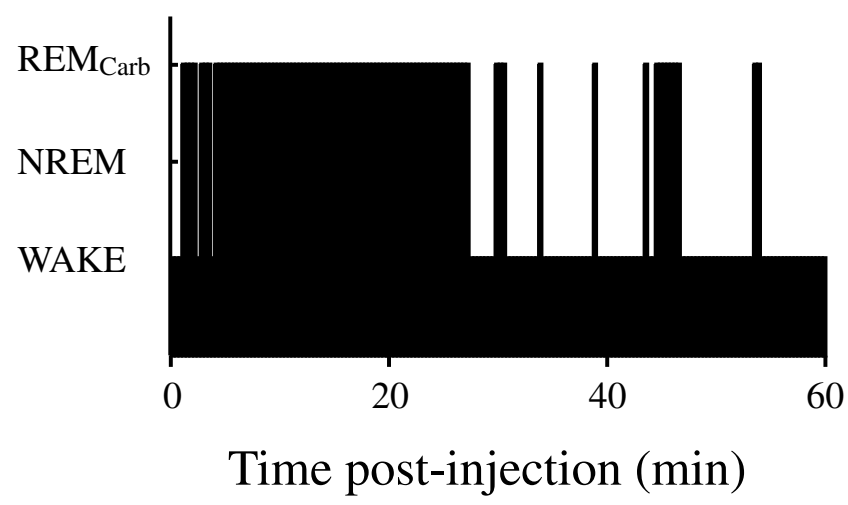

Fig. 7. Sleep and wakefulness (ordinate) plotted as a function of time (abscissa) after microinjection of $50 \mathrm{nl}$ of saline (A) or $80 \mathrm{ng}(8.8$ $\mathrm{mM}$ ) of carbachol (B) into pons of B6 mouse. Both injections were made into the same pontine site by placing a 31-gauge injector into a permanently implanted guide tube. A: During the first hour after saline administration, the mouse had one epoch of rapid eye movement (REM) sleep accounting for $1.1 \%$ of the 60 -minute recording. B: Microinjection of carbachol caused nine epochs of the REM sleep-like state $\left(\mathrm{REM}_{\mathrm{Carb}}\right)$ comprising $51.1 \%$ of the 60 -minute recording. NonREM sleep (NREM) was eliminated in the first hour after carbachol microinjection. REM sleep enhancement by carbachol is consistent with data from eight $\mathrm{B} 6$ mice, showing that microinjection of neostigmine into the oral part of the pontine reticular nucleus causes a REM sleep-like state (Lydic et al., 2002).

$\left[{ }^{35} \mathrm{~S}\right] \mathrm{GTP} \gamma \mathrm{S}$ assay have been discussed previously (Sim et al., 1995, 1997), it should be noted in the context of the present study that the assay does not resolve the specific subtypes of activated $\mathrm{G}$ proteins. The assay has been suggested to favor activation of inhibitory $G$ proteins (Kurkinen et al., 1997). In addition, in vitro stimulation of $\mathrm{G}$ proteins by carbachol may not parallel in vivo activation of $\mathrm{G}$ proteins by $\mathrm{ACh}$.

In conclusion, this study is the first to quantify cholinergically activated $\mathrm{G}$ proteins in brainstem nuclei of $\mathrm{B} 6$ mouse that are known to regulate sleep-induced alterations in arousal and nociception. The present results also provide the first comparison of cholinergically activated $G$ proteins in rat and mouse brainstem. These comparative data are in agreement with data demonstrating that cholinergically activated $\left[{ }^{35} \mathrm{~S}\right] \mathrm{GTP} \gamma \mathrm{S}$ binding is concentration-dependent and blocked by muscarinic antagonists (Kurkinen et al., 1997; Capece et al., 1998a). Sleep is a heritable phenotype in humans (Katzenberg et al., 1998; Toh et al., 2001), and sleep varies significantly as a function of mouse strain (Franken et al., 1998; Huber et al., 2000). Applying the power of mouse genetics to sleep neurobiology will require establishing causal links between genes regulating lower level phenotypes such as G proteins and higher level phenotypes such as sleep.

\section{ACKNOWLEDGMENTS}

We thank M.A. Norat, A.T. Hill, and C.A. Lapham for excellent assistance. We also thank $\mathrm{K}$. Welch and the University of Michigan Center for Statistical Analysis and Research for statistical analysis.

\section{LITERATURE CITED}

Aldrich MS. 1999. Sleep medicine. New York: Oxford University Press.

Baghdoyan HA. 1997. Location and quantification of muscarinic receptor subtypes in rat pons: implications for REM sleep generation. Am J Physiol 273:R896-R904.

Baghdoyan HA, Lydic R. 1999. M2 muscarinic receptor subtype in the feline medial pontine reticular formation modulates the amount of rapid eye movement sleep. Sleep 22:835-847.

Baghdoyan HA, Lydic R. 2002. Neurotransmitters and neuromodulators regulating sleep. In: Bazil C, Malow B, Sammaritano M, editors. Sleep and epilepsy: the clinical spectrum. New York: Elsevier Science. p 17-44.

Baghdoyan HA, Monaco AP, Rodrigo-Angulo ML, Assens F, McCarley RW, Hobson JA. 1984. Microinjection of neostigmine into the pontine reticular formation of cats enhances desynchronized sleep signs. J Pharmacol Exp Ther 231:173-180.

Baghdoyan HA, Lydic R, Callaway CW, Hobson JA. 1989. The carbacholinduced enhancement of desynchronized sleep signs is dose dependent and antagonized by centrally administered atropine. Neuropsychopharmacology 2:67-79.

Besson JM, Chaouch A. 1987. Peripheral and spinal mechanisms of nociception. Physiol Rev 67:67-186.

Bourgin P, Escourrou P, Gaultier C, Adrien J. 1995. Induction of rapid eye movement sleep by carbachol infusion into the pontine reticular formation in the rat. Neuroreport 6:532-536.

Capece ML, Baghdoyan HA, Lydic R. 1998a. Carbachol stimulates $\left[{ }^{35}\right.$ S]guanylyl 5'-(gamma-thio)-triphosphate binding in rapid eye movement sleep-related brainstem nuclei of rat. J Neurosci 18:3779-3785.

Capece ML, Baghdoyan HA, Lydic R. 1998b. Opioids activate G proteins in REM sleep-related brain stem nuclei of rat. Neuroreport 9:3025-3028.

Coleman CG, Douglas CL, Baghdoyan HA, Lydic R. 2001. Muscarinic autoreceptors in mouse oral pontine reticular nucleus $(\mathrm{PnO})$ modulate acetylcholine (ACh) release. Soc Neurosci Abstr 27:1375.

Coleman CG, Baghdoyan HA, Lydic R. 2002. Exploring muscarinic receptor subtype regulation of acetylcholine $(\mathrm{ACh})$ release in mouse pontine reticular nucleus, oral part (PnO). Soc Neurosci Abstr 28:870.5.

DeMarco GJ, Baghdoyan HA, Norat MA, Lydic R. 2001. Carbachol activates $\mathrm{G}$ proteins in pontine reticular and periaqueductal gray nuclei of C57BL/6J mouse. Soc Neurosci Abstr 27:1375.

Deurveilher S, Hars B, Hennevin E. 1997. Pontine microinjection of carbachol does not reliably enhance paradoxical sleep in rats. Sleep 20: 593-607.

Franklin KBJ, Paxinos G. 1997. The mouse brain in stereotaxic coordinates. San Diego: Academic Press.

Franken P, Malafosse A, Tafti M. 1998. Genetic variation in EEG activity during sleep in inbred mice. Am J Physiol 275:R1127-R1137.

Gonzalez-Maeso J, Rodriguez-Puertas R, Gabilondo AM, Meana JJ. 2000 Characterization of receptor-mediated $\left.{ }^{35} \mathrm{~S}\right] \mathrm{GTP} \gamma \mathrm{S}$ binding to cortical membranes from postmortem human brain. Eur J Pharmacol 390:2536.

Gordon MN, Finch CE. 1984. Topochemical localization of choline acetyltransferase and acetylcholinesterase in mouse brain. Brain Res 308: $364-368$.

Guimaraes AP, Guimaraes FS, Prado WA. 2000. Modulation of carbacholinduced antinociception from the rat periaqueductal gray. Brain Res Bull 51:471-478. 
Herkenham M, Pert CB. 1982. Light microscopic localization of brain opiate receptors: a general autoradiographic method which preserves tissue quality. J Neurosci 2:1129-1149.

Huber R, Deboer T, Tobler I. 2000. Effects of sleep deprivation on sleep and sleep EEG in three mouse strains: empirical data and simulations. Brain Res 857:8-19.

Imeri L, Bianchi S, Angeli P, Mancia M. 1994. Selective blockade of different brain stem muscarinic receptor subtypes: effects on the sleepwake cycle. Brain Res 636:68-72.

Ishizawa Y, Ma HC, Dohi S, Shimonaka H. 2000. Effects of cholinomimetic injection into the brain stem reticular formation on halothane anesthesia and antinociception in rats. J Pharmacol Exp Ther 293:845-851.

Katzenberg D, Young T, Finn L, Lin L, King DP, Takahashi JS, Mignot E. 1998. A CLOCK polymorphism associated with human diurnal preference. Sleep 21:569-576.

Kitt CA, Hohmann C, Coyle JT, Price DL. 1994. Cholinergic innervation of mouse forebrain structures. J Comp Neurol 341:117-129.

Klamt JG, Prado WA. 1991. Antinociception and behavioral changes induced by carbachol microinjected into identified sites of the rat brain. Brain Res 549:9-18.

Kryger MH, Roth T, Dement WC, editors. 2000. Principles and practice of sleep medicine. Philadelphia: W.B. Saunders.

Kshatri AM, Baghdoyan HA, Lydic R. 1998. Cholinomimetics, but not morphine, increase antinociceptive behavior from pontine reticular regions regulating rapid-eye-movement sleep. Sleep 21:677-685.

Kurkinen KM, Koistinaho J, Laitinen JT. 1997. $\left[\gamma_{-}^{35}\right.$ S]GTP autoradiography allows region-specific detection of muscarinic receptor-dependent G-protein activation in the chick optic tectum. Brain Res 769:21-28.

Leonard TO, Lydic R. 1997. Pontine nitric oxide modulates acetylcholine release, rapid eye movement sleep generation, and respiratory rate. J Neurosci 17:774-785.

Lydic R, Baghdoyan HA. 1998. Cholinergic contributions to the control of consciousness. In: Yaksh TL, Lynch C, Zapol WM, Maze M, Biebuyck JF, Saidman LJ, editors. Anesthesia: biologic foundations. New York: Raven Press. p 433-450.

Lydic R, Baghdoyan HA, editors. 1999. Handbook of behavioral state control: cellular and molecular mechanisms. Boca Raton, FL: CRC Press.

Lydic R, Douglas CL, Baghdoyan HA. 2002. Microinjection of neostigmine into the pontine reticular formation of $\mathrm{C} 57 \mathrm{BL} / 6 \mathrm{~J}$ mouse enhances rapid eye movement sleep and depresses breathing. Sleep 25:835-841.

Ma HC, Dohi S, Wang YF, Ishizawa Y, Yanagidate F. 2001. The antinoci- ceptive and sedative effects of carbachol and oxycodone administered into brainstem pontine reticular formation and spinal subarachnoid space in rats. Anesth Analg 92:1307-1315.

O'Brien SJ, Menotti-Raymond M, Murphy WJ, Nash WG, Wienberg J, Stanyon R, Copeland NG, Jenkins NA, Womack JE, Marshall Graves JA. 1999. The promise of comparative genomics in mammals. Science 286:458-481.

Owasoyo JO, Olowookorun MO. 1982. Choline acetyltransferase activity in rodent brain: a comparative study in the rat, mouse and guinea pig. Vet Res Commun 5:349-354.

Paigen K, Eppig JT. 2000. The mouse phenome project. Mamm Genome $11: 715-717$.

Paxinos G, Watson C. 1999. The rat brain in stereotaxic coordinates. Compact 3rd ed. New York: Academic Press.

Perez S, Wynick D, Steiner R, Mufson E. 2001. Distribution of galaninergic immunoreactivity in the brain of the mouse. J Comp Neurol 434:158185.

Reynolds DV. 1969. Surgery in the rat during electrical analgesia induced by focal brain stimulation. Science 164:444-445.

Sastre JP, Buda C, Kitahama K, Jouvet M. 1996. Importance of the ventrolateral region of the periaqueductal gray and adjacent tegmentum in the control of paradoxical sleep as studied by muscimol microinjection in the cat. Neuroscience 74:415-426.

Shuman SL, Capece ML, Baghdoyan HA, Lydic R. 1995. Pertussis toxinsensitive $\mathrm{G}$ proteins mediate cholinergic regulation of sleep and breathing. Am J Physiol 269:R308-R317.

Sim LJ, Selley DE, Childers SR. 1995. In vitro autoradiography of receptoractivated $\mathrm{G}$ proteins in rat brain by agonist-stimulated guanylyl $5^{\prime}-[\gamma-$ ${ }^{35}$ S] thio]-triphosphate binding. Proc Natl Acad Sci U S A 92:72427246.

Sim LJ, Selley DE, Childers SR. 1997. Autoradiographic visualization in brain of receptor-G protein coupling using $\left[{ }^{35} \mathrm{~S}\right] \mathrm{GTP} \gamma \mathrm{S}$ binding. Methods Mol Biol 83:117-132.

Sóvágó J, Dupuis DS, Gulyás B. 2001. An overview on functional receptor autoradiography using $\left[{ }^{35} \mathrm{~S}\right] \mathrm{GTP} \gamma \mathrm{S}$ autoradiography. Brain Res Rev 38:148-164

Toh KL, Jones CR, He Y, Eide EJ, Hinz WA, Virshup DM, Ptacek LJ, Fu YH. 2001. An hPer2 phosphorylation site mutation in familial advanced sleep phase syndrome. Science 291:1040-1043.

Velazquez-Moctezuma J, Shalauta MD, Gillin JC, Shiromani PJ. 1990. Differential effects of cholinergic antagonists on REM sleep components. Psychopharmacol Bull 26:349-353. 